\title{
EL ROSTRO ALEGRE DE DIOS EN LA BIBLIA
}

\author{
Miguel Ángel Garzón Moreno \\ Centro de Estudios Teológicos - Sevilla
}

\begin{abstract}
Afirma el salmista: "Dice de ti mi corazón: "Busca su rostro". Sí, Yahvé, tu rostro busco: no me ocultes tu rostro" (Sal 27,8-9). El ser humano, abierto en lo profundo de su ser a la experiencia de lo transcendente, busca conocer el "rostro" de Dios. Dentro del lenguaje bíblico la palabra "rostro" quiere expresar las experiencias religiosas personales y comunitarias, así como las imágenes literarias de la realidad divina, que son referencia decisiva de los escritos bíblicos. Ciertamente, en la Biblia, se encuentran imágenes o formas de referirse y relacionarse con Dios muy diversas según los momentos y circunstancias. En las páginas siguientes, queremos acercarnos a uno de esos aspectos del rostro de Dios que, a nuestro juicio, no ha sido especialmente subrayado en los estudios bíblicos. Nos referimos al rostro alegre de Dios en el $\mathrm{AT}^{1}$. La modalidad de trabajo es meramente descriptiva sin entrar en el análisis exegético-teológico. En primer lugar, se señalan los textos que aluden a la alegria de Dios y el vocabulario utilizado. A continuación, se hace una presentación sistemática del rostro alegre de Dios. Cierra la exposición una referencia a la alegria de Dios en el NT y unas notas conclusivas. Sirvan estas páginas como muestra de reconocimiento y agradecimiento al profesor Dr. José Arturo Domínguez Asensio, cuya sabiduria y
\end{abstract}

Comunicación presentada en el Congreso Internacional de la Asociación Bíblica Española celebrado en Sevilla los días 3-5 Septiembre de 2012, bajo el título "Los rostros de Dios en la Biblia". 
método de su quehacer "teo-lógico" fueron siempre estímulo en la búsqueda razonable y creyente del misterio del rostro de Dios.

\section{1.- LOS TEXTOS Y EL VOCABULARIO DE LA ALEGRÍA}

Los textos del AT que aluden directamente a la alegría de Dios son pocos y aparecen en todos los bloques literarios, aunque se concentran principalmente en los Profetas y los Salmos.

\begin{tabular}{|l|l|l|l|l|}
\hline Pentateuco & Históricos & \multicolumn{1}{|c|}{ Profetas } & \multicolumn{1}{|c|}{ Salmos } & Otros escritos \\
\hline $2 \mathrm{x}$ & $3 \mathrm{x}$ & $11 \mathrm{x}$ & $9 \mathrm{x}$ & $5 \mathrm{x}$ \\
\hline Dt 28,63; & Jue 9,$13 ;$ & Is 5,$7 ; 9,16(?) ; 42,1 ;$ & 2,$4 ; 16,11 ; 37,13 ;$ & Prov 8,$30 ;$ \\
$30,9$. & $1 C r 16,27 ;$ & 62,$5 ; 65,19 ; \mathrm{Jr} 31,20 ;$ & 43,$4 ; 59,9 ; 60,8 ;$ & Job 9,23;35,10; \\
& Neh $8,10$. & $\begin{array}{l}32,41 ; 33,9 ; 49,25 ; \\
\text { Bar 4,36;Sof } 3,17 .\end{array}$ & $104,26.31 ; 108,8$ & Sab 1,$13 ; 4,18$. \\
& & & \\
\hline
\end{tabular}

La alegría se presenta mayoritariamente con sus raíces específicas: שמח "alegrarse", שיל "gritar de alegria", רוש "gozar", רנן "exultar de júbilo", עלז "regocijarse", הדוה "alegria"; en los deuterocanónicos:

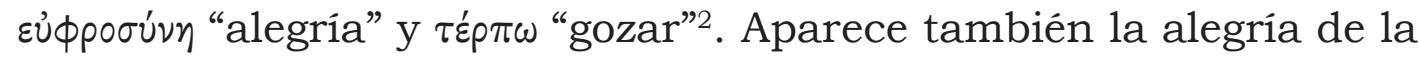
risa, como divertimento o burla, con las raíces שלעג "reír, jugar",

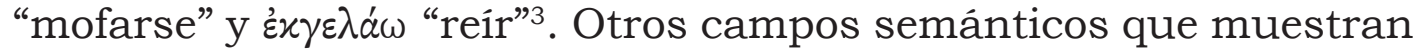

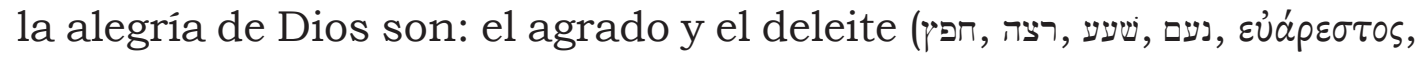

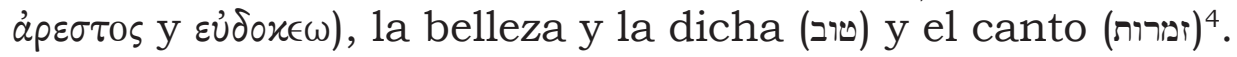

2 שמש 5x (Jue 9,13; Is 9,16; Sof 3,17; Sal 16,11; 104,31), שוש 10x (Dt 28,63.63; 30,9.9; Is 62,5; 65,19; Jr 32,41; 33,9; 49,25; Sof 3,17), גיל 2x (Is 65,19; Sof 3,17),

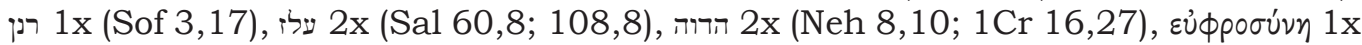
(Bar 4,36), $\tau \dot{\rho} \rho \pi \omega$ 1x (Sab 1,13).

3 שחק "jugar" 2x (Sal 104,26; Prov 8,30), שחק "burlarse” 3x (Sal 2,4; 37,13; 59,9), לעי

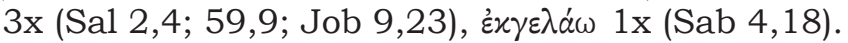

4 үפ 29x (Nm 14,8; 1Sm 15,22; 2Sm 22,20; 1Re 10,9;2Cr 9,8; Is 44,28; 48,14; 53,$10 ; 55,11 ; 56,4 ; 62,4 ;$ Jr 9,23; Os 6,6; Miq 7,18; Mal 2,17; Job 22,3; Sal $18,20 ; 35,27 ; 37,23 ; 51,8.21 ; 115,3 ; 135,6)$, רצה 21x (1Cr 28,4; 29,17; Is 42,1; Ez 20,40.41; Ag 1,8; Sal 40,14; 119,108; 147,11; 149,4; Ecl 9,7; Prov 11,1.20; 12,2.22; 15,8; 16,7; 18,22), שעע 3x (Is 5,7; Jr 31,20; Prov 8,30), נעם 2x (Sal 16,11;

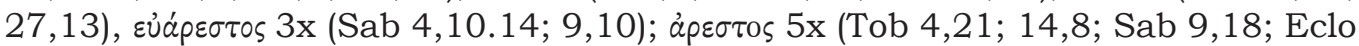

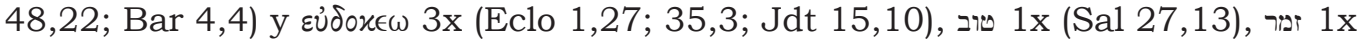
(Job 35, 10). 


\section{EL ROSTRO ALEGRE DE DIOS EN EL AT}

Al analizar estos textos y agruparlos temáticamente, podemos delinear los siguientes rasgos del rostro alegre de Dios:

\subsection{E1 rostro humano de la alegria de Dios}

La Biblia nos presenta un Dios que se alegra al modo humano bajo evidentes antropomorfismos.

- Juega con Leviatán, su juguete (Sal 104,26).

- Se alegra con el vino. En la alegoría de Jue 9 la vid afirma: "¿He de dejar mi vino, que alegra a dioses [Dios] y hombres (החדלתי את־תירושי המשמח אלהים ואנשים), para reinar sobre los árboles?” $(9,13)^{5}$.

- Se ríe y se burla. Así aparece en el nombre del patriarca Isaac יצי que podría traducirse "Yahvé sonrie", "Yahvé sonría", asociado a la raíz צחק "reír, sonreír"6. Pero fundamentalmente lo que destaca es la risa burlesca frente a aquellos que son considerados enemigos (Sal 2; 37;59; Sab 4,18).

- Se alegra como guerrero victorioso por sus conquistas militares en la batalla contra sus enemigos (Sof 3,17; Sal 60,8; 108,8).

- Goza por el amor de esposo (Is 62,5) y de padre (Jr 31,20).

- Siente agrado y deleite ante diversas realidades, principalmente la fidelidad y la justicia.

5 El vino se caracteriza por alegrar a los hombres (Sal 104,15; Ecl 10,19; Eclo 31,25-28) pero resulta singular la alusión a la alegría de Dios. Según Boling el texto hay que entenderlo en el sustrato cultural de las libaciones paganas, donde se tenía la conciencia de que tanto los dioses paganos como los adoradores se alegraban con las bebidas (cf. Judges, AB 6A, 173). En este sentido אלהים dentro de la fábula se podría traducir por "dioses", pero en ámbito yahvista se requiere el singular. La LXX tiene el singular.

6 Es la forma abreviada de yishaq-el "sonría Dios" o "sea propicio Dios" 
- Canta en la noche. El capitulo 35 del libro de Job ofrece una imagen peculiar de Dios. Habla Elihud para derribar los argumentos de Job acerca de un Dios que no le importa la inocencia del hombre. Invita a mirar al cielo y defiende a Dios que calla ante el mal de los opresores, pues los que están bajo la opresión no preguntan “¿Dónde está Dios, mi hacedor, que proclama cánticos en la noche?" (איה אלויה עשי נתן זמרות בלילה 35,10). Si se mantiene la traducción se dibuja la imagen de Dios cantando en la noche. ${ }^{7}$

\subsection{La alegría de Dios con su creación}

Dios experimenta la alegría con sus criaturas, goza con la "bondad" de su creación.

- Se alegra al ver la belleza-bondad de su creación

Los relatos de la creación no aluden explícitamente a la alegría de Dios. Con todo, se podría percibir un matiz de alegría en el estribillo "y vio Dios que era bueno" (Gn 1,4.10.12.18.21.25), "muy bueno" (1,31). Se repite siete veces, como los dias de la creación. La última tiene su peculiaridad, pues añade el adverbio de cantidad "muy" y se refiere a toda la obra realizada por Dios una vez acabada (טירא אלהיים את־כל-אשר עשה והנה־טוב מאר). La raíz "bueno" posee un amplísimo campo semántico cubriendo la totalidad de matices semánticos de la bondad. En el texto expresa esta totalidad de la bondad, belleza, armonía de la creación. Podemos deducir que para Dios la contemplación de su obra colmada de belleza-bondad le llena de alegría ${ }^{8}$. Esta alegría llega a plenitud al completar su obra con el ser humano, afirmando que todo era "muy bueno". Tal

\footnotetext{
La LXX traduce זמרות por "refugio". Algunos autores optan por "fuerzas" siguiendo el árabe y ugarítico (cf. Ex 15,2; Is 12,2; 25,5; Sal 118,14; cf. M. H. Pope, Job, AB15, 229; Alonso Schökel-Sicre, Job, 497). Los que traducen por "cantos" (זיר) dan varias interpretaciones: los cantos de liberación de los oprimidos (cf. Is 30,29); cantos de angustia (cf. J. E. Hartley, The Book of Job, NICOT, 466); cantos de los opresores; el huracán; la música de las esferas celestes que no advierten los oprimidos (cf. Alonso Schökel-Sicre, Job, 497). Pero ninguna traducción pone a Dios como sujeto de los cánticos cuando la construcción verbal así lo pide.

8 Cf. Alonso Schökel-Carniti, Salmos II, 1306.1312
} 
deducción la podemos colegir del texto opuesto de la anti-creación en el diluvio. Dios observa la corrupción de su creación, la "maldad" de los hombres (ר, Gn 6,5) ${ }^{9}$. Esto le lleva a arrepentirse de su creación y "se entristeció de corazón" (6,6) ויתעצב אל-לבו 6)

\section{- Se alegra con sus criaturas}

Encontramos un eco del relato del Génesis en el Salmo 104, bello himno a Dios por su creación. El salmista va cantando las maravillas de las obras (מעשים) de Dios que hizo con sabiduria (v. 24), él las crea y sostiene con su espíritu (v. 30). Entre ellas está "Leviatán, al que formaste para jugar con él (לויתן זה־יצרת לשחק־ב Sal 104,26) ${ }^{11}$ ". El texto desmitifica la figura del Leviatán, reduciéndolo a criatura y a un juguete con el que Dios se recrea en el agua. Más adelante el salmo pide que se dé gloria al Señor y "que el Señor se alegre con sus obras (ישמח יהוה במעשיו v. 31)”. La alegría de Dios con sus obras es un signo de la armonía de la creación, motivo para su gloria (כבוד).

Como contrapunto, el inicio del libro de la Sabiduría afirma que "Dios no hizo la muerte ni se alegra con la muerte de los vivientes (o" $\tau$ เ

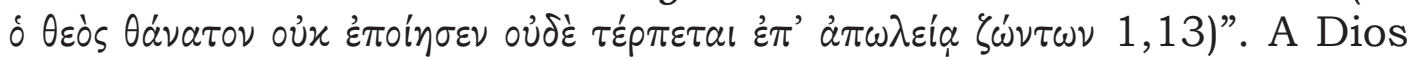
sólo le compete la vida, la muerte no forma parte de sus obras sino que ésta entró en el mundo por envidia del diablo $(2,24)$. Dios no se deleita con la corrupción, ruina o muerte de los vivientes ${ }^{12}$.

9 6,5: וירא יהוה כי רבה רעת האדם בארץ וכל-יצר מחשבת לבו רק רע כל־היום. Nótese la presencia del término רוב "malo", el antónimo deno" de Gn 1.

10 Este es uno de los pocos textos que aluden a la tristeza de Dios. La raíz עצב "entristecerse" (opuesta a la alegría en Neh 8,10) también se aplica a Dios en: Is 63,10 (el pueblo rebelde "entristeció su santo espíritu") y Sal 78,40 ("le entristecieron en las soledades"). En Is 65,3 Dios denuncia las afrentas (כעס) que le provocan los pecadores, que hacen lo que no le agrada (צפ 65 65,12;66,4). Para la tristeza de Dios ver E. Jacob, "Le Dieu souffrant, un theme théologique vétérotestamentaire», ZAW 95 (1983) 1-8.

11 La interpretación es ambigua: ¿Quién se alegra? ¿Cómo traducir la preposición z? Una opción es aplicar el infinitivo constructo לשחק al Leviatán y traducir la preposición como "en", siendo así Leviatán el que juega en el mar. Pero preferimos tomar a Dios como sujetoy traducir la preposición z como “con”. Job 40,29 elimina muchas ambigüedades al usar el mismo verbo con la misma preposición referida a Leviatán: “¿Jugarás con él como con un pájaro (התשחק־בו כצפור)?". Cf. M. Dahood, Psalms III (AB 17A), 45; Alonso Schökel-Carniti, SalmosII, 1311-1312.

12 El verbo $\tau \dot{\rho} \rho \pi \omega$ significa "saciar, deleitarse, regocijarse"; y el sustantivo ảmo $\lambda \in \iota \alpha$ refiere la destrucción material, moral o física. 


\subsection{La alegria de Dios con su pueblo}

Unaspecto importante corresponde a la alegría que Dios experimenta con su pueblo.

\section{- El pueblo es la delicia de Dios}

Isaías afirma en la alegoría de la viña:"La viña del Señor de los ejércitos es la casa de Israel y los hombres de Judá el plantio de sus delicias (שעישועים)" (5,7)" con el posesivo remite al deleite que Dios experimenta con el pueblo. La imagen contiene también el matiz de alegría que implica la viña. Este dulce gozo se convierte en amargura al constatar la maldad y violencia de su pueblo ${ }^{13}$.

Por su parte, Jeremías habla del deleite de Dios bajo la metáfora paterno-filial. En los bellos poemas del c. 31, Dios, a corazón abierto por la rebeldía de su pueblo, se pregunta: “¿No es Efraín un hijo precioso para mí? ¿No es un niño de delicias?” (v. 20). Efraín es el niño que llena de deleite (שעטשועים) a Dios, se convierte en causa de gozo para él. Por esta cualidad del pueblo Dios se refrena en el ador de su ira y se mueve a compasión, como un padre o una madre ante su hijo querido (בן יקר).

El deleite o agrado de Dios con su pueblo también se muestra en otros textos, así: Nm 14,8; Ez 20,40.41; Sal 149,4. Específicamente, su agrado y complacencia está: en el humilde (Sal 18,20), en la paz de su siervo (Sal 35,27), en el justo(Sal 37,23; Ecl 9,7; Prov 11,20; 12,2.22; 15,8; 16,7; Sab 4,10.14; Eclo 35,3), en los que le temen (Sal 147,11 ), en David (2Sm 22,20; 1 Cr 28,4), en Salomón (1Re 10,9; $2 \mathrm{Cr}$ 9,8), en el siervo (Is 42,1), en las acciones de Judit (Jdt 15,10). Las

13 La maldad del pueblo también motiva la no alegría de Dios en Is 9,16: "Por eso el Señor no se alegra con sus jóvenes" (על-כן על-בחוריו לאישמח אדני), aunque el texto es muy dudoso. La referencia a la alegría (שמח) resulta extraña y se ha propuesto un cambio a la raíz שמח "apiadarse" para adecuarlo al paralelo "compadecerse". Si se mantiene el TM (como la LXX) Dios se queja de la actitud rebelde y de la resistencia a la conversión por las que les ha sobrevenido la ruina. Por esto, el Señor no puede alegrarse a causa de sus jóvenes, ni se apiadará de sus huérfanos y viudas. 
actitudes que le agradan son: la obediencia (1Sm 15,22), la rectitud (1Cr 29,17), la misericordia, el derecho y la justicia (Jr 9,23; Os 6,6; Miq 7,18), la verdad (Sal 51,8), la fidelidad y la humildad (Eclo 1,27), las ofrendas justas (Sal 51,21), los pesos justos (Prov 11,1) ${ }^{14}$.

\section{- El gozo por el castigo y la salvación de su pueblo}

Particularmente significativos son los textos que presentan el gozo de Dios al otorgar a su pueblo la bendición o la maldición: hacerles el mal o el bien. Así lo recoge el libro del Deuteronomio. El c. 28, dedicado a las bendiciones y maldiciones que el pueblo recibirá de acorde a su fidelidad o infidelidad una vez que haya tomado posesión de la tierra, afirma: "Así como el Señor se gozaba en haceros bien y en multiplicaros, asi se gozará el Señor en arruinaros y en destruiros" (v. 63). El texto marca dos momentos: uno pasado, de bendición, donde Dios gozaba (שוש) al hacerles dichosos (היטיב); y otro futuro, de maldición, en el que Dios gozará (שוש al hacerlos perecer. La alusión a la destrucción vaticina la desgracia del destierro. Pero un poco más adelante, el c. 30 continúa profetizando lo que sucederá en el destierro si el pueblo se convierte al Señor y vuelve a la fidelidad. Dios tendrá misericordia de ellos y cambiará su suerte (vv. 3.10). Dios anuncia las bendiciones que le esperarán al pueblo como fruto de su conversión y obediencia: el éxito de sus empresas y la fecundidad plena, "porque el Señor volverá a alegrarse contigo para bien, como se alegraba con tus padres" (כי ישוב יהוה לשוש עליך לטוב כאשר־ש על־אבתיך v. 9). Como consecuencia de la conversión (שוב) del pueblo, el Señor anuncia que volverá (שוב) a alegrarse con su bien-felicidad (טוב cf. v. 5), como lo hizo con sus padres.

El profeta Jeremias ofrece un paralelo de estas expresiones del Deuteronomio en el texto de la compra del campo de Janamel

14 Por el contrario no encuentra agrado: en su pueblo pecador (Jr 14,10; Mal 1,10), en sacrificios vacíos, en la maldad (Is 1,11 ; Jr 14,12; Os 6,6; 8,13; Am 5,21; Miq 6,7; Mal 1,10.13; 2,13; Sal 40,7; 51,18), en la muerte del malvado (Ez 18,23.32; $33,11)$. Otros textos sobre el agrado de Dios: encuentra agrado en el templo reconstruido (Ag 1,8); el pueblo piensa que Dios se complace con los malvados (Mal 2,17 ), los amigos de Job se preguntan si a Dios le agrada que Job sea justo (Job $22,3)$, el justo pide que Dios se complazca en salvarle (Sal 40,14), en aceptar los sacrificios de su boca (Sal 119,108). 
(c. 32). En el largo discurso a Jeremías, Dios anuncia el destierro como consecuencia de las perversiones del pueblo, pero volverán los desterrados, ocuparán las tierras de Judá y se renovará la alianza. En este punto apostilla: "me alegraré a causa de ellos haciéndoles el bien" (וששתי עליהם להטיב אותם v. 41). Como les trajo una gran desgracia, les traerá esta gran bondad-felicidad (v. 42). Al igual que en el Deuteronomio, se subraya la alegría de Dios ligada a su misericordia y perdón.

Dios también muestra su gozo al conquistar y repartir la tierra a su pueblo. Así, en los salmos 60,8 y 108,8 se repite la misma frase como respuesta de Dios a la súplica del pueblo que le pide que salga a combatir con ellos frente al acoso de los enemigos: "Dios dice en su santuario": Exultaré al repartir Siquén y al medir el valle de Sucot)". Dios responde presentándose como guerrero, señor de todos los territorios, y mostrándose victorioso frente a los enemigos. Gozará (עלז) al distribuir la tierra entre su pueblo.

\subsection{La risa de Dios frente a los enemigos}

Este último texto nos permite enlazar con la risa burlona de Dios frente a sus enemigos o los enemigos de sus fieles: poderosos (naciones, reyes, príncipes), malvados o necios.

Así lo muestran los Salmos 2, 37 y 59. El orante del salmo 2, después de presentar las asechanzas de los reyes y príncipes de la tierra contra el Señor, de quien no aceptan su soberanía ni la de su ungido, afirma: "El que se sienta en los cielos se rie (ישחק), el Señor se burla (ילעג) de él (v. 4)”. El Salmo sapiencial 37 narra cómo el malvado planea el mal contra el justo y se burla de él. Pero "el Señor se reirá (ישח) de él, pues ve que viene su fin" (v.13); ellos, enemigos del Señor, perecerán (v. 20) y salvará al justo. El Salmo 59 presenta la suplica del justo que se siente amenazado por sus enemigos (vv. 1.11): malhechores y sanguinarios (v. 3); poderosos (v. 4); paganos y rebeldes (v. 6). Sólo encuentra esperanza y confianza en el Señor, "tú, Señor, te reirás (תשחק) de él, te burlarás (תלעג) de toda nación” v.9). La risa de

\footnotetext{
15 O: "Promete por su santidad".
} 
Dios fortalece al justo y le hace cantar de alegría. La burla de Dios, es la del rey soberano, del que se siente superior y señor de la historia ${ }^{16}$.

También el libro de la Sabiduría afirma que los impíos e injustos verán la muerte del sabio pero no entenderán el porqué."Mirarán y

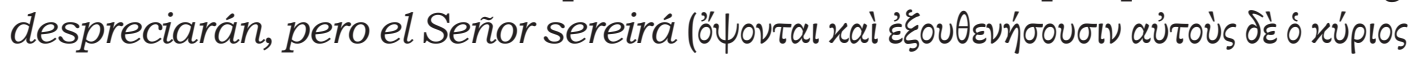
$\left.\varepsilon \dot{\varepsilon} \gamma \varepsilon \lambda \alpha_{\alpha} \sigma \varepsilon \tau a l ~ 4,18\right) " 17$. Dios con la muerte ha sacado al justo de un ambiente tentador de perversión e injusticia, mientras que los malvados, al morir, quedarán burlados y en la ignominia eterna, sin memoria ${ }^{18}$.

\section{- ¿La risa maléfica de Dios?}

Job, sin embargo, acusa a Dios por su risa maléfica. Habla desde su sufrimiento y su consideración de inocente. Describe a Dios como aquél que desde su señorío sobre la creación y los designios del mundo lo sigue golpeando con calamidades, y no responde a su queja. No se puede declarar justo delante de Dios, porque lo consideraría injusto, es más, destruye tanto al íntegro como al impío $(9,22)$. En este punto afirma: "Si una calamidad mata de repente, de la desgracia de los inocentes él se rie (למסת נקים ילעג $9,23)^{19}$ ". Job no ve salida a su situación y se enfrenta a un Dios que le supera y del que no entiende tal comportamiento ${ }^{20}$. Habrá

16 "Nosotros hablamos de la ironía de la historia, entendiendo un desenlace imprevisto e inesperado, que se vuelve contra los protagonistas, de los cuales se burla la historia como entidad trascendente, capaz de la distancia que le pide la ironía. Para el orante, la instancia trascendente, distante para mirar y capaz de abarcar el proceso hasta su desenlace, es el Señor. Por eso se rie" (SchökelSicre, Salmos I, 559).

17 Mismo verbo (' $\epsilon \kappa \gamma \in \lambda \alpha \omega)$ que usa la LXX en Sal 2,4; 37,13; 59,9.

18 La Sabiduria también se rie de la desgracia de los necios e insensatos: Prov 1,26 "También yo me reiré (אשיח) de vuestra desdicha, me burlaré (איגל) cuando os llegue el espanto".

19 La "desgracia (מסת)" vendría de la raíz מסט "disolver". Otros proponen: "prueba" (de

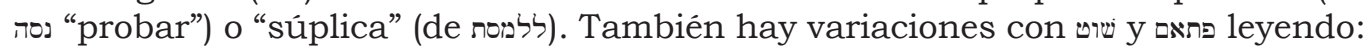
"Si la burla puede matar a los inocentes, ¿por qué se burla de las pruebas del justo?", o "Aunque el azote mate a los necios, él se burla también de la desgracia de los inocentes". En cualquier caso no se pierde la referencia a la risa de Dios frente a los inocentes. Cf. Alonso Schökel-Sicre, Job, 177.

20 Recordemos las afirmaciones del Eclesiástico: "no te rias ( $\kappa \alpha \tau \alpha \gamma \in \lambda \alpha \omega)$ del hombre afligido" $(7,11)$; "no te regocijes (' $\epsilon$ $\leftarrow \chi \alpha\llcorner\rho \omega)$ de la muerte de nadie" $(8,7)$. Rashi aplica la frase de Job a Satán y no a Dios. 
que esperar al final del libro para que Job entre en el silencio y deje hablar a Dios. Entonces se le mostrará como Dios creador, alejado del mal, al que tiene a raya. Job comprenderá que habló sin sentido de cosas que no entendia, de maravillas que le superan. Conocia a Dios de oídas y ahora lo han visto sus ojos.

\subsection{La alegria con su ciudad: Sión-Jerusalén}

Al igual que con su pueblo, Dios se alegra con Jerusalén-Sión. Unas veces aparece como la ciudad santa, su morada. Otras veces, personificada como su esposa y madre del pueblo.

- Jerusalén, ciudad de la alegría de Dios

En el profeta Jeremías, Diosafirma: Jerusalén "será para mí, nombre de gozo, alabanza y orgullo ante todas las naciones" (33,9 לשם ששון לתחלה לתפאתת) La ciudad salvada es motivo de gozo para el Señor ante las naciones y la alegría llenará todo el territorio. Dios también llama "ciudad de mi gozo" (שרית 49,25) a Damasco, abandonada por sus habitantes en la calamidad. Pero el texto refleja irónicamente la alegría de Dios por la desgracia de la ciudad enemiga; su caída se ha convertido en motivo de gozo ${ }^{22}$.

El final del libro de Sofonías recoge uno de los textos que mejor muestra la alegría de Dios con Sión, y que incluso más subraya de forma explícita la alegría de Dios en la Biblia. El Señor anuncia la restauración de la ciudad santa, la purificará de todo engreído y orgulloso, dejando un resto pobre y humilde. Invita a cantar de gozo a Jerusalén, a que prorrumpa en gritos de júbilo, pues Dios la ha perdonado y en ese día de salvación habrá expulsado

21 El texto no cita a Jerusalén. Se pude referir a la acción salvífica que el Señor va a hacer al pueblo. La LXX lo aplica a los paganos. Pero por el contexto y el femenino del verbo y del sufijo de la última palabra del versículo ("todo el bien que le hago a ella"), preferimos ver implicita la ciudad. Cf. J. Lundbom, Jeremiah 21-36, AB21B, 532-533; Alonso Schökel, Profetas, Vol. I, 574.

22 Algunos autores toman como sujeto de la alegría a un habitante de Damasco, o al profeta (cf. Lundbom, Jeremiah 37-52, AB21C, 350-351), o quitan el sufijo: "ciudad alegre" (Sir, Tg, Vg, cf. W. Holladay, Jeremiah 2, 379-380). 
todos sus enemigos. Dios, rey de Israel, vive en su interior, como guerrero que salva. Él se alegrará por ella: “Se gozará por ti con alegría, te renovará con su amor, exultará por ti con gritos de júbilo" (ישיש עליך בשמחה יחריש באהבתו יגיל עליך ברנה 3,17). El versículo concentra cuatro raices de alegría que subrayan fuertemente el gozo del Señor. La imagen es la del guerrero victorioso que exulta de gozo por la salvación de Jerusalén, manifestando su alegría con estruendosos gritos de júbilo. También está presente el amor de Dios que renovará a la ciudad ${ }^{23}$. Un amor misericordioso.

\section{- Dios goza con Jerusalén, su mujer-esposa}

El amor de Dios por su ciudad da un paso más cuando Jerusalén se personifica como esposa del Señor y goza con su amor. Así lo muestra el Tercer Isaías en un bello oráculo de salvación donde Dios proclama la restauración de Jerusalén y el cambio de su situación. Ya no más será llamada abandonada ni desolada sino que se le llamará "Mi delicia en ella" (חפיי-בה) y a su tierra "Desposada" $(62,4)$. Se presenta la alegria de Dios bajo la forma del deleite. La ciudadmujer es su deleite, en/con ella se deleita (כי־חפץ יהוה בך). El siguiente versículo muestra el gozo de los desposados: "Como desposa el joven a la doncella asi te desposa tu constructor, y como el gozo del esposo con la esposa asi gozará por ti tu Dios" (משוש חתן על-כלה ישיש עליך אלהיך $62,5)$. La imagen evoca el gozo de la relación nupcial en todos los sentidos, desde la compañía al encuentro amoroso y sexual. E1 poema expresa la belleza del amor de juventud, donde Dios y la ciudad-mujer gozan de su amor. La luz del amanecer ilumina la ciudad que parece una corona en la mano de Dios (cf. Prov 12,4). Esta luz irradia la frescura del día de bodas en el que el rey después de defender la ciudad y devolverle su esplendor le da un nuevo nombre, la desposa y goza con ella ${ }^{24}$.

23 Leemos con la LXX la raíz חדרש al hifil "renovar" en vez de חרש "estar callado" (TM).

24 Se sobreponen varias imágenes: el amanecer del sol-rey, del rey guerrero victorioso, de la ciudad corona, de la tierra desposada como madre, los desposorios, el arquitecto. Leemos el TM בניך con otra vocalización: no "tus hijos" sino "tu constructor". Quizá un escriba ha cambiado por razones teológicas la vocalización produciendo un texto incoherente con el contexto, cf. Alonso Schökel, Profetas, I, 374. 


\section{- La alegría que viene de Dios a Jerusalén}

Los cc. 4-5 del libro de Baruc tienen en la alegría un motivo central. En 4,36 se invita a Jerusalén a mirar a oriente y contemplar

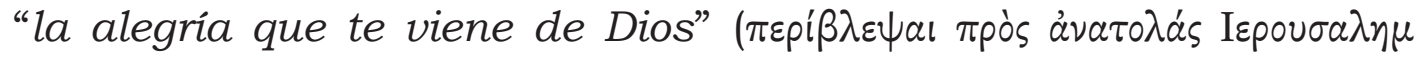

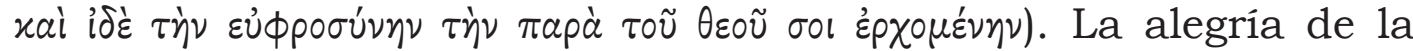
ciudad viene de Dios, en él tiene su origen $(4,29)^{25}$. Lo mismo que vino la ira de parte de Dios y la llenó de tristeza (Bar 4,9.2526), ahora viene la alegría, que es eterna $(4,23.29)$. Por el paralelismo con el versículo siguiente, la alegria la representan los hijos que vuelven del oriente alegres por la gloria de Dios $(4,37)$. Se unen, así, la alegría de Dios, la de Jerusalén-madre y la del pueblo. El cap. 5, continúa la invitación a la alegría de Sion por los hijos que vuelven alegres a ella. Concluye el poema indicando que Dios trae "con gozo" a Israel a la luz de su gloria. Aunque la expresión puede aludir tanto al gozo de Dios como al del pueblo, el paralelismo con 4,37 hace que nos decantamos por los israelitas.

\subsection{El gozo de Dios con su pueblo y con Jerusalén en la nueva creación}

El bello oráculo de la nueva creación en el final del libro de Isaías $(65,16 b-25)$ contiene otra de las afirmaciones con mayor carga teológica sobre la alegría de Dios. La creación de los cielos nuevos y la tierra nueva pone fin al tiempo de las tribulaciones antiguas para dar paso al tiempo de la felicidad plena, con la llegada de un nuevo mundo cargado del gozo de las bendiciones de Dios. La nueva creación conlleva la creación del pueblo y de Jerusalén en alegria: "Pues he aqui que yo voy a crear a Jerusalén en alegria y a su pueblo en gozo" (משוש 65,18). La nueva identidad, la esencia del pueblo y de Jerusalén es el gozo y la alegría. Dios entonces añade: "y me alegraré con Jerusalén y gozaré

\footnotetext{
25 Traducimos la preposición rapà con genitivo como "de, de parte de", siendo Dios la procedencia de la alegria; mismo uso en Bar 4,9.22.24.25; 5,1.2.9. Otra opción es traducir "por medio de" y ver a Dios como agente de la alegría (cf. 5,4$)$.

26 Se usa la misma construcción ( $\pi$ apà $\tau$ đoũ $\theta \varepsilon \circ \tilde{u}$ ) para la ira de Dios que llega a Jerusalén.
} 
con mi pueblo" (וגלתי בירושלם וששתי בעמי v. 19)27. Si el v. 16b ya aludia indirectamente a la alegría de Dios (porque la tristeza-tribulación desaparece de sus ojos), ahora se afirma positivamente: Dios gozará con la nueva situación creada, compartirá la alegría de la ciudad (ירושלם) y del pueblo que vive en ella (v. עמה 18) y que le pertenece (v. עמי 19 , cf. v. 10). El posesivo "mi pueblo" (עמי) expresa la intimidad entre Dios y el pueblo fruto de la relación de alianza. Así como la ruptura de la alianza entristece a Dios $(63,10)$, puesto que el pueblo escoge aquello que no le agrada $(65,12 ; 66,3)$, la fidelidad lo llena de alegría puesto que el pueblo sigue lo que le agrada: la justicia y el derecho $(56,1-2.4 ; 58,2)$.

\subsection{La alegria de la presencia-rostro de Dios}

Una dimensión muy sugerente y profunda de la alegría de Dios es la que se deduce de los textos que hablan de la alegría de la presencia de Dios, ante su rostro, en su cara, en su morada. Aparece fundamentalmente en los salmos.

El salmista del Sal 16 expresa su confianza en el Señor cuya continua presencia le otorga seguridad. Concluye su oración manifestando su alegría al saber que Dios no lo dejará en el sheol, sino que le enseñará un camino de vida y experimentará la "saciedad de alegría en tu presencia, dulzura en tu diestra eternamente" (שבע שמחות את־פניך נעמות בימינך נצח v. 11). ¿De quién se predica la alegría y la delicia? El sentido espontáneo del texto es la alegría del $\mathrm{fiel}^{28}$. Pero también se puede interpretar desde la alegría de Dios. Los plurales שמחות "dulzura" son plurales de intensidad, y se pueden entender como complementos de materia (así Dahood), remitiendo a la alegría y dulzura de Dios "con la que" se sacia el fiel

27 Se retoman por tercera vez en el contexto los verbos גיל y שוש. La preposición ב unida a ambas raíces alude a la alegría compartida de Dios con Jerusalén y su pueblo. Pero también puede indicar el motivo: la alegría por Jerusalén y su pueblo creados como alegría. En 61,10 el pueblo se alegra con/por (גיל ב ,שוש ב) su Dios que confiere la salvación. Ahora es Dios quien se alegra con/por su pueblo.

28 Para ello, incluso, se ha propuesto modificar la vocalización del sustantivo שבע para cambiarlo a un infinitivo absoluto. Cf. Dahood, Psalms I (AB 16), 91. 
(cf. טובה en v. 2). Se proclama la alegria ante el rostro (פנים) de Dios ${ }^{29}$. Un rostro cuya felicidad se trasmite al que llega ante su presencia y permanece alli junto a su diestra. La misma expresión aparece en el Sal 21. El salmista presenta la dicha del rey que festeja la fuerza de Dios que le ha dado la victoria, lo ha colmado de bendiciones y "lo llenas de alegría en tu presencia" (תחדהו בשחמה את־ניך v. 7) 730.

El Sal 27 alude a la "búsqueda del rostro de Dios" (פנים vv. 8-9). El orante desea: "ver la dulzura del Señor (לחזות בנעם-יהוה v.4)" en su templo y "contemplar la bondad del Señor en la tierra de los vivos" (לראות בטוב־יהוה בארץ חיים v. 13). El término נעם significa "dulzura, delicia" e incluso la belleza ${ }^{31}$. El término טוּ remite a la bondad de Dios, también en el sentido de la belleza ${ }^{32}$, o incluso en cuanto "dicha, felicidad". Ambos se presentan como atributos de Dios, que le son propios, que se ven y se contemplan ${ }^{33}$. El salmista anhela ver la belleza de Dios y participar de su felicidad ${ }^{34}$.

En esta misma perspectiva, el orante del Sal 43 suplica a Dios en su angustia para que se haga presente y le defienda frente al enemigo. Pide su luz para llegar hasta su monte santo, su morada. Alli se acercará al altar de Dios ${ }^{35}$. Un Dios que define como: אל שמחת גילי (v. 4). La traducción de este sintagma depende de cómo interpretar el

29 La expresión אתיפניך se traduce por "a tu rostro", o "con tu rostro", "contigo".

30 La preposición ₹ "con" puede interpretarse, de nuevo, como complemento de materia.

31 Así Dahood, Psalms I, AB 16, 167.170, "loveliness" (sigue la raíz correspondiente en Ugarit); también Schökel-Carniti, Salmos I, 436.443: (“disfrutar de la belleza"). La LXX opta por "delicia" con un término $(\tau \in \rho \pi \nu o ́ t \eta \tau \alpha)$ que solo aparece en el texto emparentado de Sal 16(15),11

32 Así Dahood, y Alonso Schökel-Carniti. El mismo sentido en Ex 33,19; Os 10,11; Zac 9,17. La LXX traduce por "bienes" ( $\tau \dot{a}$ à $\gamma a \theta \dot{a}$ xupíov).

33 Como atributos de Dios, נעם: Sal 90,17 ("y venga la delicia del Señor sobre nosotros"); 135,3 / שוב: Ex 33,19; Sal 25,7; 31,20; 145,7. Muy sugerente es Ex 33,19: Moisés pide al Señor ver su gloria, y él accede haciendo pasar ante él toda su "belleza-bondad" (אני אעביר כל-טובי) pero lo cubrirá con su palma para que no vea su rostro.

34 Las expresiones חזה ב (v. 4) y ראה ב (v. 13) implican el ver con deleite, el disfrute visual.

35 La expresión בוא אל indica acercarse, situarse junto a Dios. El Sal 43 está intimamente unido al Sal 42 (incluso para leerlos juntos, cf. Alonso Schökel-Carniti, 610), el cual expresa el anhelo de "entrar a ver el rostro de Dios" (v. 3) en la casa de Dios (v. 5). 
término גילי Aיל Tomándolo como el extraño sustantivo periodo de vida" se traduciría por "Dios de la alegría de mi vida"36. Considerando el sustantivo más común גיל "gozo", el texto presenta un sintagma raro en la sintaxis y duro de traducir, quizá como expresión adjetival "Dios de mi gozosa alegria"37. En cualquier caso, el orante define a Dios como su alegría plena, es decir, alegría en sí mismo y alegría que se participa, convirtiéndose en causa de la alegría del creyente.

En 1 Cr 16 David ordena a los encargados de la custodia del Arca de la Alianza alabar a Dios con un bello himno. El himno invita a "buscar siempre el rostro de Dios (בקשו פניי v. 11)", a "entrar en su presencia (באו לפניו v. 29)". Ante este rostro están los atributos propios de Dios: "La majestad y la gloria se encuentran ante Él, la fuerza y la alegría en su lugar (הוד והדר לפניו עז וחרוה במקמו v. 27)". El término חרוה "alegría", por su contexto, puede referirse a la alegría que le tributan los distintos elementos celestiales y terrestres; pero, por los paralelos, es mejor entender la alegría que es propia de Dios, como la majestad (הוד), el esplendor (הדר) y el poder (ער) (עיר) El texto nos presenta la alegría que se encuentra en la morada de Dios junto a esos otros atributos característicos de su naturaleza ${ }^{39}$. El paralelismo con estos términos hace de la alegría una realidad propia, que sale de Dios, que irradia, que resplandece.

El término חדוה también refiere la alegría de Dios en la famosa exhortación de Neh 8,10: "no os entristezcáis porque la alegría del Señor es vuestra fortaleza" (ואל־תעצו כי־חדות יהוה היא מעזכם). El sentido del

36 Mismo significado en Sal 2,11; 22,9; 139,15; Dn 1,10; así Dahood, Psalms I (AB 16, 262); K-B, 190. La LXX también así: "Dios que alegra mi juventud" (mpòs tòv

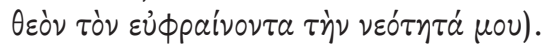

37 Alonso Schökel-Carniti, 612 ("al Dios de mi gozo y alegría"). BDB, 162 y Zorell, 150 incluyen ambas raices pero citan Sal 43,4 en este sentido de "gozo".

38 El texto es una cita del Sal 96,6 pero cambiando חדוה por. Atributos de Dios: majestad (1Cr 29,11; Job 37,22; 40,10; Sal 8,2; 21,6; 96,6; 104,1; 111,13; 145,5; 148,13; Hab 3,3), esplendor הדר (Sal 29,4; 45,5; 90,16; 96,6; 104,1; $111,13$; 145,5.12; Job 40,10; Is $2,10.19 .21)$; poder 1 (1Cr 16,11.28; Sal 21,2.14; 59,$17 ; 62,12 ; 63,3 ; 66,3 ; 68,29 ; 77,15 ; 86,16 ; 93,1 ; 96,6 ; 105,4$; Is 45,24; Miq 5,3; Hab 3,4). El sustantivo הדוה solo tiene tres ocurrencias: Neh 8,10; Esd 6,16 y $1 \mathrm{Cr} 16,27$ de la misma tradición literaria.

39 La expresión לפניו "ante él" alude a la presencia de Dios. Mientras que la expresión מקומו morada celestial de Dios. 
texto reside en la interpretación del constructo "alegría del Señor" (הרות יהוה). Si se lee como genitivo objetivo se trata de la alegría (del pueblo) por el Señor, probablemente la alegría de las fiestas y los banquetes sagrados que pone fin a la desdicha que había surgido en el pueblo al considerar su infidelidad a la Alianza cuando se leyó la ley ${ }^{40}$. Pero optamos por un genitivo subjetivo: la alegría que es de Dios. El pueblo debería encontrar un motivo para ser fuertes y no estar tristes. El texto es más coherente si esa fuerza no es de ellos, es decir, de su alegrarse en las fiestas, sino de fuera, la alegría de Dios, asociada a su gloria, su esplendor y su fuerza (cf. $1 \mathrm{Cr}$ $\left.16,27^{41}\right)$. Otra interpretación posible: la alegría de Dios es que seáis fuertes, Dios se alegra con vuestra fortaleza.

\subsection{La alegria de Dios con la Sabiduria y la Palabra}

Un texto dificil de interpretar pero con sugerentes implicaciones teológicas es Prov 8,30-31. La Sabiduría está hablando sobre su origen y misión en la creación. El v.30 afirma que ella estaba junto a Dios, "yo era (su) delicia cada día (ואהיה שעטשים)" ע2 y "jugaba ante su rostro en todo tiempo (משחקת לפניו כל-עת)" El v. 31 continúa: "jugaba

40 Así H.G.M. Williamson (WBC 16, 281.292). Este es el sentido del término שמחה en el versículo siguiente. En Esd 6,16 el vocablo הרוה refiere la alegría del pueblo en la dedicación del templo. La LXX quita esta referencia a la alegría.

41 El término עי "fuerza" que junto a הדוה "júbilo" aparece en 1Cr 16,27 como atributo divino tiene la misma raíz que מעז en Neh 8,16.

42 Literalmente: "Yo era delicias día a día". El sustantivo שעשעים es un plural de abstración. Como en el versículo siguiente se puede sobrentender un posesivo: "su delicia", la de Dios. Siguiendo el paralelismo de la primera frase, la Sabiduría es, junto a Dios, artesano-criatura y delicia. Ser la delicia de alguien es ser la fuente de su delicia (Cf. Is 5,7; Jr 31,20; Sal 119,24). Dios, antes que la Sabiduría, es quien experimenta el deleite (cf. Fox, Proverbs 1-9, 287; la Biblia de Jerusalén traduce: "yo era su alegría cotidiana"). Otros lo aplican a la Sabiduría, en paralelo al verbo שח (cf. Alonso Schökel-Vilchez, Proverbios, 239: "yo estaba disfrutando cada día").

43 No entramos en la complejidad textual del inicio del v. 30: "yo estaba junto a él, como criatura (אמון " אמון plede significar "artesano" (Alonso SchökelVilchez, 242), "constantemente" o "criatura". Fox opta por esta última, "ward/ nursling", pues en los vv. 30-31 "Wisdom is declaring that while God was busy creating the world, she was near him, growing up in his care and living him delight". Añade: "the broader theme of playing for the amusement of a god, as a cultic processionals, is well attested and may belong to the background of the present verse" (AB 18A, 285.288). 
con/en el mundo de su tierra (משחקת בתבל ארצו) y mis delicias están con los hombres (ושעשעי את־בני ארם) ${ }^{44}$. La imagen que se describe es la de una criatura junto a Dios que juguetea ante él, y cuya presencia y comportamiento le provocan deleite y alegría. La sabiduría se presenta, así, como la delicia de Dios. Al mismo tiempo, el texto señala el gozo de la propia sabiduria al jugar delante de Dios en cada momento, y ser la delicia de los hombres ${ }^{45}$. La Sabiduría se comporta así de intermediaria entre Dios y los hombres, entre la alegría de Dios y la de los hombres. En esta labor mediadora la sabiduría tiene la importante cualidad de enseñar "a los hombres lo

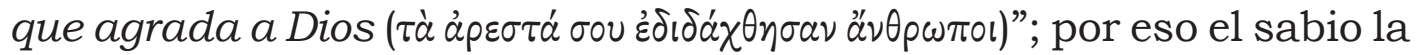
pide a Dios: "Enviala desde el cielo sagrado, mándala desde tu trono glorioso, para que esté a mi lado y trabaje conmigo, enseñándome lo

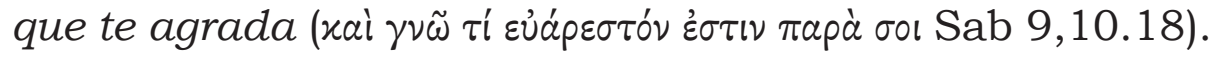

En relación con el agrado de Dios se encuentra también su Palabra. Dios habita en el cielo y puede realizar en cielo y tierra siempre lo que le place, lo que le agrada (Sal 115,3; 135,6). Pero su querer también depende de mediadores. En el bello poema conclusivo del Segundo Isaías, Dios afirma que la palabra que sale de su boca no volverá a Él de vacío sino hasta cumplir lo que le agrada (כי אם־עשה את־אשר חפצתי). Su palabra se convierte en agente de realización de su alegría ${ }^{46}$.

Estos últimos textos permiten establecer una conexión directa con el Nuevo Testamento. El papel de mediación de la Sabiduría y la Palabra lo vemos cumplido en Jesucristo (cf. 1Cor 1,24.30; Jn $1,14)$, cuya misión remite a Dios y a los hombres.

44 La expresión ב שחק ב puede traducirse: “jugar con" o “jugar en". Por otro lado, el sufijo en "mis delicias" (שעשעי) puede indicar el deleite de la sabiduría con la humanidad o el deleite que da la sabiduría a los hombres. La composición quiástica de los dos versículos (yo era delicia- yo jugaba-yo jugaba- mi delicia) orienta hacia la delicia que la sabiduría provoca o da a los hombres. Con todo, se pueden aunar las dos: la Sabiduría es quien siente el deleite que a su vez es gozo para los seres humanos. Cf. M. Fox, Proverbs 1-9, AB 18A, 288-289. La BJ traduce: "compartiendo mi alegría con los humanos".

45 Otros textos afirman también la alegría de la Sabiduría: Prov 1,26; Sab 8, 16.

46 Otros que realizan el agrado de Dios: Ciro (Is 44,28; 48,14), el siervo (Is 53,10), Ezequías (Eclo 48,22). Israel conoce lo que agrada a Dios (Bar 4,4). Los que realizan el agrado del Señor alcanzan dicha: eunucos (Is 56,4), Tobías (Tob 4,21; $14,8)$. Los malvados hacen lo que no agrada a Dios (Is 65,$12 ; 66,4$ ). 


\section{LA ALEGRÍA DE DIOS EN EL NT}

El Nuevo Testamento también contiene textos que remiten a la alegría de Dios, sea por boca de Jesús o de otros. Jesús habla de la alegría de Dios, fundamentalmente en las parábolas de la misericordia. Así, en el evangelio de Mateo, dentro de la parábola de la oveja perdida, Jesús describe el gozo del pastor al encontrar

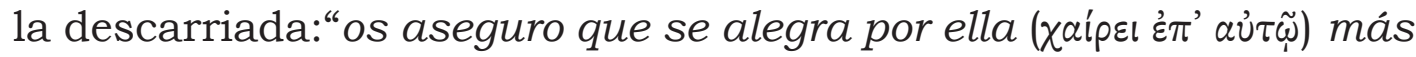
que por las noventa y nueve que no se extraviaron" $(18,13)$. El texto revela la gran alegría del Padre del cielo que no quiere que ninguno se pierda, pero que cuando recupera al que se ha descarriado su corazón exulta de júbilo.

El evangelio de Lucas es el que plasma las afirmaciones más significativas sobre la alegría de Dios en el grandioso capítulo 15 con las tres parábolas de la misericordia del Padre. Jesús narra en la parábola ya señalada de la oveja perdida: "Al encontrarla, se

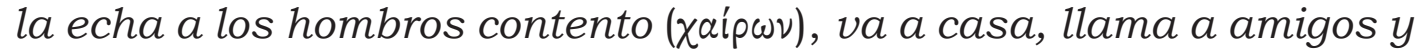

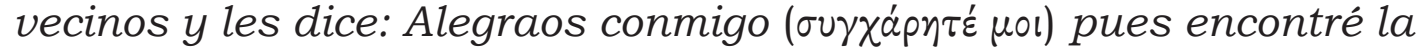
oveja perdida" (Lc 15,5.6.7). Jesús ratifica dicha alegria: "Os digo

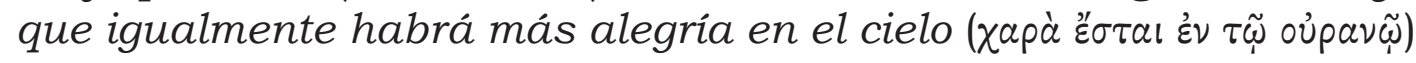
por un solo pecador que se convierte que por noventa y nueve justos que no tienen necesidad de conversión" $(15,7)$. Y en la parábola de la dracma perdida: "Al encontrarla, llama a las amigas y vecinas

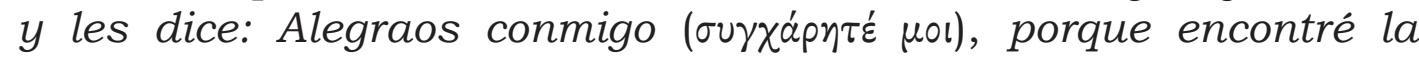
moneda perdida". $(15,9)$. Y corrobora diciendo: "Os digo que lo

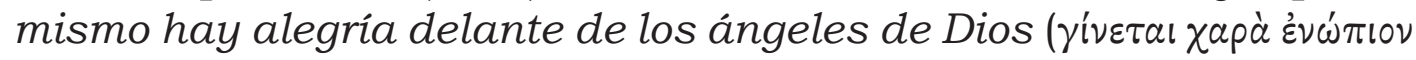

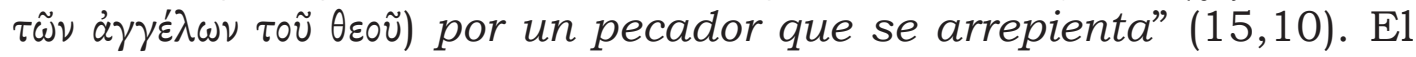
texto alude a la alegría de Dios y de su ámbito (cielo y ángeles son eufemismos para no nombrar a Dios). La alegría que está delante de los ángeles es la alegría de Dios. Finalmente, en la parábola del hijo pródigo, cuando el hijo menor vuelve a casa, dice el padre: "Traed el ternero cebado y matadlo. Celebremos un banquete

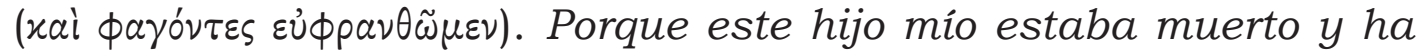
revivido, se habia perdido y ha sido encontrado. Y empezaron la

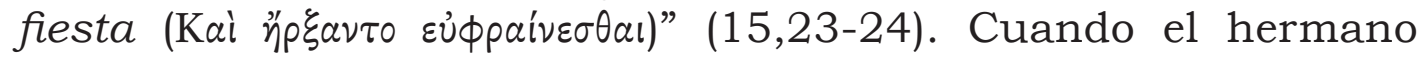
mayor recrimina al padre que nunca le ha dado un cabrito para regocijarse con sus amigos, el padre le contesta:"Habia que hacer

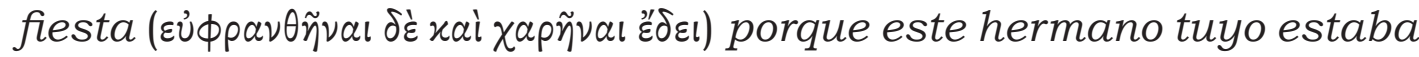
muerto y ha revivido, se habia perdido y ha sido encontrado" 
$(15,32)$. Aquí se unen la alegría y el gozo de la celebración de un banquete. De nuevo, se trata de la alegría del padre (Dios) que ha de ser compartida por los demás.

Otros textos del NT también permiten atisbar la alegría de Dios. Así en $1 \mathrm{Tm}$ 1,11 se define a Dios con la expresión: "de acuerdo

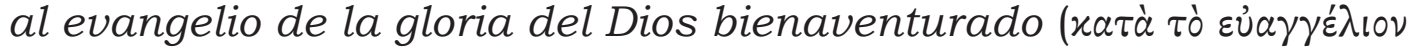

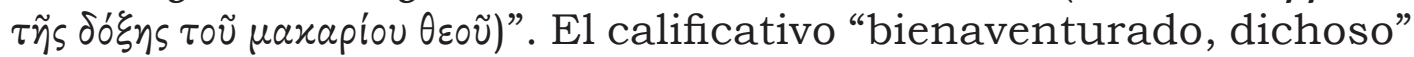
califica a Dios, en una expresión única en la Biblia. Hace de la dicha un atributo de Dios. Otros textos remiten a lo que agrada a $\operatorname{Dios}^{47}$.

\section{CONCLUSIÓN}

\section{a) E1 rostro alegre de Dios}

¿Podemos hablar del rostro alegre de Dios? Como hemos visto, ciertamente sí. El rostro de Dios se presenta en la Biblia con una gran variedad de matices. Entre ese gran espectro de rasgos se encuentra la alegría. Dios goza y se alegra. Del recorrido realizado podemos decir que la alegría de Dios tiene estas características:

- Dios se alegra al modo humano: juega, rie, se burla, goza, exulta... Los motivos también son humanos, se alegra con: sus juguetes, sus conquistas, el amor de padre y esposo, la caída del enemigo, el bien de su pueblo,... Es el rostro revelado en la experiencia de fe de un pueblo que contempla a Dios desde sus propias coordenadas humanas, un Dios que se ha hecho accesible a la razón y al lenguaje humano y se deja describir por ese mismo lenguaje.

472 Cor 5,9 "En cualquier caso, en la patria o desterrados, aspiramos a serle agra-

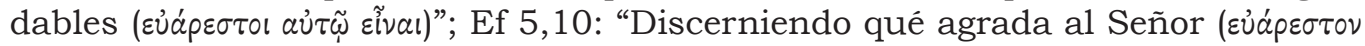
$\tau \tilde{\omega}$ xupí( ))"; Heb 13,16.21: "No descuidéis la beneficencia y la solidaridad: tales son

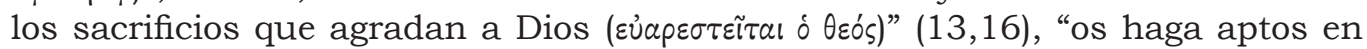
toda obra buena para que hagáis su voluntad, haciendo él en vosotros lo que es

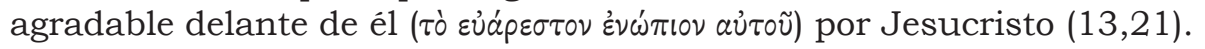


- La alegría forma parte del mismo ser de Dios, es un atributo divino. Su bondad-alegría aparece junto a otros elementos propios de su ser. Su rostro es alegria, dulzura, belleza. Dios se muestra como lugar-ámbito donde está, sale y se irradia la alegría, una alegría que se comunica y se da a otros para que gocen de ella. Se trata de un aspecto que enlaza con lo más propio de Dios, su gloria.

- Esta bondad-alegría se plasma en su obra creadora, que a su vez se erige en motivo de la alegría de Dios al contemplarla.

- Dios se rie de todo lo que atenta contra esa huella de la bondad: el mal-pecado y los enemigos. El mal se convierte en obstáculo para la alegría de Dios y la alegría de la creación. Pero su risa revela que el mal no triunfa sobre él, sobre su plan de salvación. Su risa es manifestación de poder, de señorío sobre la historia. Se muestra como guerrero exultante por sus conquistas.

- La alegría de Dios aparece relacionada especialmente con su pueblo y su ciudad Jerusalén. Establece una relación especial: de padre-hijo, de esposo-esposa. Esta relación de amor le llena de alegria. Con su salvación, Dios quiere hacerles el bien, hacerles felices. La felicidad del pueblo y de la ciudad por su salvación llena de gozo a Dios.

- El plan de salvación culmina con la nueva creación. La nueva creación consiste en la alegría, en la recuperación de la bondad-alegría original. Dios compartirá esta alegría con su creación renovada. Dios crea al pueblo y a la ciudad en alegría, los convierte en alegría y gozo. Y él participará de esta misma alegría.

\section{b) E1 Rostro que revela la alegria de Dios}

Si la alegría humana se convierte en camino para revelar a Dios, podemos decir que el rostro alegre de Dios es un rostro al modo humano. Esta modalidad de revelación toma su máxima expresión en el tiempo del NT, donde la humanidad se convierte en camino directo de revelación divina. Moisés no pudo ver el rostro de Dios, 
cuando hizo pasar su bondad ante él (Ex 33,19). Este Rostro nos lo ha revelado el Hijo. Con sus palabras, Jesucristo nos ha hablado del rostro de Dios Padre que se alegra por sus hijos, especialmente por sus hijos perdidos y retornados a casa donde participan de la alegría divina.

Pero además, Jesucristo es la Palabra hecha carne (Jn 1,14), que trae la alegría de Dios a los hombres. En él, Dios se ha humanado y ha dado a conocer su rostro. El rostro gozoso del Padre es revelado por el Rostro gozoso del Hijo. Jesucristo en su alegría nos ha hecho visible la alegria de Dios. En su alegria ha acontecido la nueva creación. Una alegría en donde la humanidad encuentra el camino de la alegría plena, que es imagen y semejanza de la alegría de Dios. Así lo presenta Jesús en su discurso de despedida, tal y como narra el evangelio de san Juan: "Os he dicho

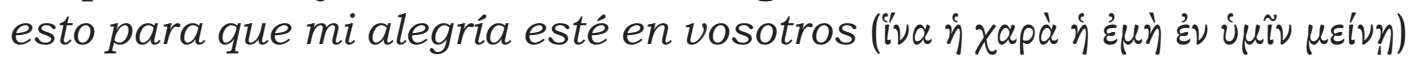
y vuestra alegria llegue a plenitud" (15,11); "para que tengan mi

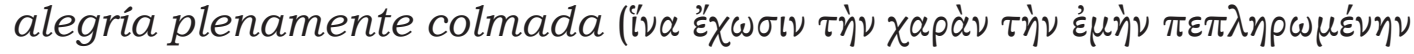
ย่v aủंoĩs 17,13$) " .48$

El Hijo al afrontar su misterio pascual colma su alegría ante el rostro del Padre. Así lo afirma Pedro en su discurso después de Pentecostés al aplicar el salmo 16 a Jesús resucitado de la muerte: "David dice refiriéndose a él: Pongo siempre delante al Señor: con él a la derecha no vacilaré. Por eso se me alegra el corazón, y goza

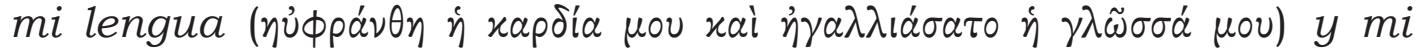
carne descansa esperanzada: porque no me dejarás en la muerte ni permitirás que tu fiel conozca la corrupción. Me enseñaste el camino de la vida, me llenarás de gozo en tu presencia ( $\pi \lambda \eta \rho \omega ́ \sigma \varepsilon ı \varsigma$

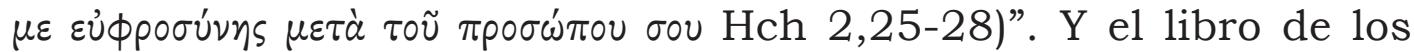
Hebreos lo corrobora de modo sugerente: "El cual, por el gozo

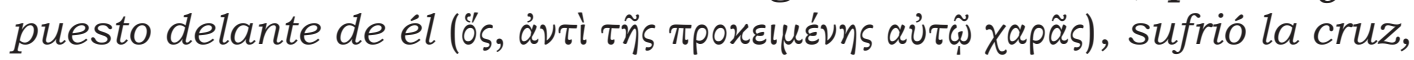
despreció la humillación y se ha sentado a la diestra del trono de Dios" $(12,2)$. El Señor Jesús soportó los ultrajes de la pasión y

48 Otros textos de la alegría de Jesús: Después de la misión de los setenta y dos:

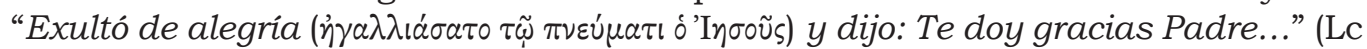

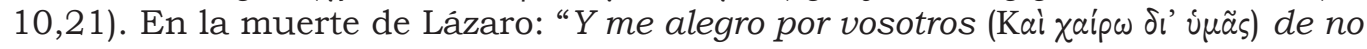
haber estado alli, para que creáis" (Jn 11,15). 
la cruz por la alegría puesta delante, es decir, por la alegria que esperaba alcanzar. ${ }^{49}$

Desde ese lugar de gloria y triunfo junto al Padre, el Hijo comparte la alegria como atributo divino. Una Alegria divina, que será para todo el que se haga fiel servidor de su Reino, como nos ha prometido en la parábola de los talentos: "Muy bien, siervo honrado y cumplidor; has sido fiel en lo poco, te pongo al frente de lo

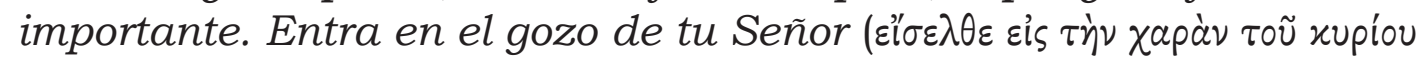
oov Mt 25,21.23)".

49 Se completa la visión de la alegría de Dios en el NT con la alegría del Espíritu Santo. Algunos textos unen ambos términos: "Los discípulos quedaron llenos de

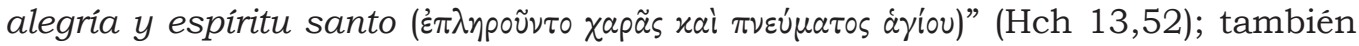
lo hace Pablo en el saludo de su primera carta a los tesalonicenses, "acogisteis

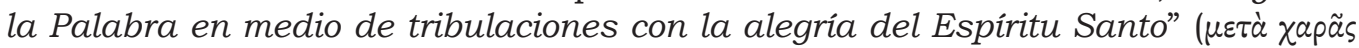
$\pi \nu \varepsilon \dot{\mu} \mu a \tau o s$ áyíov 1Tes 1,6), identifica la alegría que viene del Espíritu Santo con el

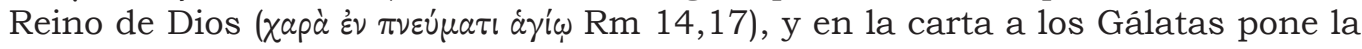
alegría dentro de los frutos del Espíritu ( $\chi$ apà 5,22 ). 